IRSTI 06.71 .45

UDC 338.012

https://doi.org/10.46914/1562-2959-2021-1-1-110-115

\author{
T.S. KOROTKOVA, ${ }^{1}$ \\ MSc. \\ e-mail:ktctania@mail.ru \\ D.I. ZAKIROVA, ${ }^{2 *}$ \\ $\mathrm{PhD}$. \\ *e-mail: ulasdila@gmail.com \\ ${ }^{1}$ Innovative University of Eurasia, \\ Kazakhstan, Pavlodar \\ ${ }^{2}$ Turan University, Kazakhstan, Almaty
}

\title{
ENVIRONMENTAL EDUCATION AND EDUCATION FOR SUSTAINABLE DEVELOPMENT: GENERAL AND SPECIAL
}

\begin{abstract}
The ideological basis of education for sustainable development is primarily formed by environmental education. It is an essential component and the first step in the development of education for sustainable development. The article examines the relationship between environmental education and education for sustainable development, their standard features and distinctive features. Education for sustainable development is inextricably linked with environmental education. Each of these areas, being independent, can develop together with more effectively. The principles declared by the Tbilisi Declaration and faced with the shortcomings of environmental education can be implemented through education for sustainable development. Education for sustainable development can effectively use traditional environmental education's positive achievements, complementing economic, social, and cultural contexts. The new paradigm of sustainable development education involves solving many problems related to the formation of education as the leading social institution and the development of a new system of values. It is necessary to ensure close interaction of education with social, political and cultural processes, strengthen the connection between education and science, ensure informatization and greening of education, etc. However, it is necessary to solve the problem of understanding education for sustainable development as education about sustainable development.
\end{abstract}

Key words: sustainable development, environmental education, ecology, education, declaration, information, environmentalization.

The study of implementing education for sustainable development demonstrates the complexity and urgency of this problem at the present stage of development. There are two main approaches to understanding the essence of education in the context of sustainable development.

On the one hand, it is viewed as a direction of environmental education. Indeed, historically, these two directions exist in close interconnection: they consider issues that provide an understanding of the processes occurring in ecosystems, cause the ability to feel and understand nature, form the education of respect for all living things, cause concern for the state of the environment, and desire to solve social and environmental problems.

On the other hand, education for sustainable development is seen as an independent direction in developing pedagogical theory and practice. Scientists argue that, unlike environmental education, sustainable development education considers environmental and social and economic aspects of the environment.

The study of this issue has shown that not everything is so simple. At one time, the Intergovernmental Conference in Tbilisi held back in 1977, defined the goal of environmental education as «promoting awareness of the interdependence of the economic, social, political and environmental aspects of the environment» [1]. The fundamental requirements for education that prepares a person for whole life in a world filled with environmental problems were formulated in the Tbilisi Declaration. The concept of sustainable development, adopted in 1992 in Rio de Janeiro, relied entirely on the Tbilisi Declaration about educational requirements. The further development of ideas in this area led to an emphasis on 
the social and spiritual, and moral aspects of special education, helping a person choose solutions to sustainable development. Later it was called education for sustainable development.

Thus, the lack of consideration of social and economic factors is more likely a flaw in environmental education, but not its difference from education for sustainable development. Moreover, in considering the three dimensions of the environment, education for sustainable development is not broader than environmental education.

It is necessary to conduct a detailed examination of both directions of education.

Environmental education is commonly understood as a continuous process of training, upbringing and personal development, aimed at forming scientific and practical knowledge and skills, value orientations, behaviour and activities that ensure a responsible attitude to the environment and health. Environmental education aims to form an individual and society's environmental culture as a set of the practical and spiritual experience of interaction with nature, ensuring human survival and development. In international documents and the practice of environmental education in foreign countries, the term «environmental education» emphasizes the practical orientation of education in the field of environmental protection.

Sustainable development education aims to form a comprehensively educated, socially active person with an ecological culture, understanding new phenomena and processes of social life. The person owns a system of views, ideological and moral values about the future development of civilization, cultural and ethical principles, norms of behaviour that ensure readiness for social responsibility and lifelong learning in a rapidly changing world. Sustainable development education aims to help students embrace values, develop knowledge and skills that will enable them to make further individual and collective local and global decisions to improve the quality of life without endangering the planet's future [2].

Several general points can be distinguished by analyzing the definitions, goals, and essence of environmental education and sustainable development education.

Firstly, the achievement of both directions of education is associated with forming an individual's worldview, aimed at foreseeing global environmental catastrophes, understanding the essence of environmental laws, the causes of conflicts in the «nature-society» system. It is confirmed by the UN Conference on Environment and Development (Rio de Janeiro in 1992), after which environmental education began to be considered the ideological basis of education for sustainable development [3].

Secondly, the unifying feature is the formation of responsibility, which implies the humanization of education in order to form a universal human priority of preserving the environment and bridging the gap between knowledge, consciousness, emotions, attitudes and activities; creation of options for the content and forms of education in changing conditions.

The following general point is the study of problems of a global nature, which have put humanity in front of international cooperation in this area.

Continuity is also standard in these directions. In the 90s, environmental education began to be given priority among the factors in the conclusion of environmental problems. In this regard, the concept of continuous environmental education arose, which enriches an individual and society's environmental culture throughout human life. The Strategy [4] also defines sustainable development education as a lifelong process, from early childhood to higher education, and goes beyond formal education. The guiding principles are the unity of the intellectual and emotional perception of the natural environment and practical activities to improve it; systematic and continuous education; its interdisciplinarity; interconnection of global, national and regional approaches to environmental problems.

Also uniting these two processes, of course, is ecological culture. It acts as a combination of human interaction with nature, ensuring human survival and development and expressed in the form of theoretical knowledge and methods of practical action in nature and society, moral norms, values and cultural traditions.

Also, the achievement of the above goals of environmental education and education for sustainable development is associated with the implementation of the following general principles: the formation of an ecological, educational environment; creating conditions for creative expression; axiological principle; ecohumanistic principle; the principle of communication with real significant environmental problems. 
Despite the standard features of environmental education and education for sustainable development, we adhere to the second approach to understanding the latter. We will try to justify why education for sustainable development is an independent direction of education.

Based on the analysis of studies on this issue, we identified differences in goals, forms, approaches, methods and conditions between environmental education and sustainable development education.

First, the goal of sustainable development education is broader than it is outlined in the context of environmental education. The model of education for sustainable development considers the growth of the individual and assumes the formation and formation of certain personal qualities and the creation of conditions for their development.

Secondly, an approach to the issue of the relationship between society and nature. In environmental education, the principal place is occupied by the priority of the anthropocentric approach or the ecocentric approach. In sustainable development education, it is not the dominant position of one of the above approaches that are important. But the establishment of a balance, complementarity and mutual balance between anthropocentrism and ecocentrism.

The third difference is related to the moral aspect, which traditionally distinguishes environmental education from education in other sciences. The concept of ethics is evolving. Early ethical norms determined the relationship between individuals; later ethical principles extended to the relationship between a person and society. One of the categories of the concept of sustainable development, the concept of environmental ethics, implies responsibility for human life and the evolution of the biosphere, not only in the present but also in the future. Modern environmental education calls for «keeping the planet clean» here and now. Education for sustainable development is forward-looking and aimed at long-term prospects. Its most important feature in the future category - to limit oneself here and now to preserve the planet for future generations and provide them with opportunities to meet their needs. Thus, education for sustainable development is forward-looking, forms the outstripping consciousness of people, making them able to deal with global crisis phenomena.

Fourth, in education for sustainable development, the relationship «man-nature» is subjectsubjective. Unlike environmental education, it allows us to consider nature not as an object of influence but as a communication subject.

Fifth, the model of education for sustainable development, based on the subject-subject interpersonal relationship of the teacher and students, implies more significant attention to the student's personality and equal interaction between the student and the teacher in the process of achieving a common educational goal.

Besides, the subjects of environmental education are mainly schoolchildren and students. Education for sustainable development involves the participation of all population segments, regardless of age and social status. It aims to raise public concern about the state of the environment and awareness of each participant's importance and contribution to this society.

Sixth, conditions conducive to achieving the goal of sustainable development education. Traditionally, environmental education is associated with a system of prohibitions. The model of education for sustainable development is based on students' motivation, determined by the emotional and sensory experience of nature and supported by knowledge in the field of natural and humanitarian disciplines. In education, motivation is viewed as a condition for the formation of conscious, environmentally sound behaviour and a factor that can make environmental problems personally significant for children. The conscious socially significant activity aimed at harmonizing relations with the environment is seen as the main result of education for sustainable development.

The education system for sustainable development presupposes that education will become a self-organizing system. Its very existence in society will have a priority character. That is, in this case, we can speak of an «educational society». In understanding this, a holistic (holistic) approach to education for sustainable development is essential, according to which the world is viewed as an integral all-encompassing system.

Moreover, the main fundamental difference between environmental education and education for sustainable development lies in understanding the essence of civilization's current global crisis as an environmental one and a management crisis. The concept of sustainable development is a response to a crisis resulting from society's inability to adapt to rapidly changing environmental conditions, loss of 
the ability to self-regulation and effective management. The way out of the crisis lies in changing the interaction between human-made systems and nature, social systems, which education can provide.

Also, researchers dealing with the problem of the development of modern education in the context of the concept of sustainable development highlight the following features: diversity, which is expressed in the difference in information flows (subjects, courses, teaching methods, etc.), a variety of forms of the educational process (personal communication with a teacher, online communication via the Internet, etc.); revealing a balance between natural science and humanitarian knowledge; greening the educational process and creating a system of environmental education; predictiveness of education, which presupposes the orientation of consciousness to «outstripping» the actual processes and trends of the predicted future.

At the same time, the paradigm of education for sustainable development is not opposed to «ecological», «natural science», «holistic», «fundamental», «humanistic» and other paradigms. It most holistically embraces planetary reality: global, environmental, demographic, social, and geopolitical problems. It implies organic interweaving of the teaching on sustainable development into the educational process, the implementation of natural science and humanitarian education, and conditions for broad environmental education and upbringing.

The systematic patterns of the formation of the paradigm of education for sustainable development occur in two stages: the stage of formation of consciousness, understanding and belief about the phenomenon of sustainable development; the stage of the formation of such behaviour and activities.

In modern society, education is becoming an essential factor guiding society towards sustainable development. It is essential to understand that society's sustainable development cannot be carried out if there is no constant learning, acquisition and understanding of new experience. In this regard, education for sustainable development must be seen as an ongoing process through which society must learn to live more environmentally, economically and socially.

Education for sustainable development is designed to develop the intellectual potential of society. It should become the primary basis for forming a high-quality living environment and social equality, form motivation, a system of values and a social base for the search for knowledge and its practical application [5].

It is important to note that the competence-based approach was identified as one of the methodological approaches in the program for the modernization of education. The proposed approach is consistent with the understanding of the fundamental goals of sustainable development education to learn to acquire knowledge (teach to learn), learn to live (the ability to be), learn to work (the ability to work), learn to live together (teaching for a communal life).

It should be noted that sustainable development education is not a new subject in the curriculum. Telling students what sustainable development is is a change in approaches to education:

- for students - from a passive assimilation of information to its active search and critical reflection, use in practice, to communication and activity;

- for teacher - from the transfer of knowledge to the creation of conditions for active knowledge and practical experience for students;

- for an educational institution - to change the policy of managing a team of adults and children, using resources, organizing interaction with the local community.

These tasks can be solved by improving all aspects of the life of an educational institution: educational process, educational environment, social partnership, management of available resources.

Within the framework of the educational process, one can rely on the main content lines of education for sustainable development: interrelationships (in society, economy and nature); human rights and responsibility; the needs and rights of future generations; diversity - cultural, social, biological; quality of life and social justice; the future is predictable and unpredictable.

As a result of the implementation of the idea of sustainable development in the educational process, it will achieve the following results:

- the state of the environment in and around the educational institution is improving;

- students are brought up to be responsible for making decisions and for their consequences, and their civic position; 
- summarizes and systematizes the work on various environmental topics and aspects of sustainable development;

- cooperation is being established with residents and various organizations, as well as with the local administration;

- the social climate in the educational institution is improving;

- energy and water consumption decreases, the number of waste decreases;

- the school receives additional funds, for example, for the delivery of recyclable materials for recycling or energy savings;

- knowledge about the environment is expanding; an ecological aspect is introduced into existing school courses:

- international cooperation of educational institutions is expanding.

Thus, education for sustainable development is, on the one hand, an interdisciplinary area of knowledge that includes natural sciences, social, economic disciplines and systems sciences. On the other hand, it includes the process of teaching, upbringing, self-development, self-realization, focused on the formation of critically thinking, spiritually wealthy and socially active citizens. These citizens will base their practical actions on environmental ethics principles, contribute to the solution of existing and prevention of new environmental problems.

\section{LIST OF LITERATURE}

1 Intergovernmental Conference on Environmental Education. - Tbilisi, October 14-26, 1977: https:// www.gdrc.org/uem/ee/EE-Tbilisi_1977.pdf.

2 Tbilisi Communiqué «Educate today for a sustainable future». - Tbilisi, September 6-7, 2012: http:// www.aaee.org.au/wp-content/uploads2/2009/07/Tbilisi-Communique.pdf.

3 Report of the United Nations Conference on Environment and Development. - Rio de Janeiro, June 3-14, 1992.

4 United Nations Economic Commission for Europe Strategy for Education for Sustainable Development.Vilnius, 2005: https://unece.org/esd-strategy.

5 Korotkova T.S., Zakirova D.I. Sustainable development of higher education in a modern economy // Научный журнал «Вестник университета «Туран». - 2020. - № 4(88). - C. 121-127. https://doi. org/10.46914/1562-2959-2020-1-4-121-127.

\section{LIST OF LITERATURE}

1 Intergovernmental Conference on Environmental Education. - Tbilisi, October 14-26, 1977: https:// www.gdrc.org/uem/ee/EE-Tbilisi_1977.pdf.

2 Tbilisi Communiqué «Educate today for a sustainable future». - Tbilisi, September 6-7, 2012: http:// www.aaee.org.au/wp-content/uploads2/2009/07/Tbilisi-Communique.pdf.

3 Report of the United Nations Conference on Environment and Development. - Rio de Janeiro, June 3-14, 1992.

4 United Nations Economic Commission for Europe Strategy for Education for Sustainable Development.Vilnius, 2005: https://unece.org/esd-strategy.

5 Korotkova T.S., Zakirova D.I. (2020) Sustainable development of higher education in a modern economy // Nauchnyj zhurnal «Vestnik universiteta «Turan». № 4(88). pp. 121-127. https://doi.org/10.46914/ 1562-2959-2020-1-4-121-127. 
Т.С. КОРОТКОВА, ${ }^{1}$

магистр.

e-mail: ktctania@mail.ru

Д.И. ЗАКИРОВА, $2 *$

$\mathrm{PhD}$.

*e-mail: ulasdila@gmail.com

${ }^{1}$ Еуразия Инновациялық университеті,

Қазақстан, Павлодар қ.

${ }^{2} \ll$ Тұран» университеті, Қазақстан, Алматы қ.

\title{
ЭКОЛОГИЯЛЫҚ БІЛІМ ЖӘНЕ ТҰРАҚТЫ ДАМУҒА АРНАЛҒАН БІЛІМ: ЖАЛПЫ ЖӘНЕ ЕРЕКШЕ
}

\section{Андатпа}

Тұрақты даму үшін білім берудің дүниетанымдық негізін экологиялық білім құрайды. Бұл тұрақты даму үшін білім беруді дамытудың маңызды құрамдас бөлігі және бірінші кезеңі. Мақалада экологиялық білім беру мен тұрақты даму үшін білім берудің өзара байланысы, олардың жалпы белгілері мен ерекшеліктері қарастырылады. Тұрақты даму үшін білім беру экологиялық біліммен тығыз байланысты. Осы бағыттардың әрқайсысы тәуелсіз бола отырып, бірге тиімді дамуға қабілетті. Тбилиси декларациясында жарияланған және экологиялық білімнің кемшіліктеріне тап болған принциптер тұрақты даму үшін білім беру арқылы жүзеге асырылуы мүмкін. Тұрақты даму мүддесі үшін білім беру дәстүрлі экологиялық білімнің жағымды жетістіктерін экономикалық, әлеуметтік және мәдени аспектілермен толықтыра отырып тиімді қолдана алады. Тұрақты даму үшін білім берудің жаңа парадигмасы білім берудің негізгі әлеуметтік институт ретінде қалыптасуына, сондай-ақ құндылықтардың жаңа жүйесін дамытуға байланысты бірқатар міндеттерді шешуді көздейді. Білім берудің әлеуметтік, саяси және мәдени процестермен тығыз өзара іс-қимылын қамтамасыз ету, білім берудің ғылыммен байланысын күшейту, білім беруді ақпараттандыру мен экологияландыруды қамтамасыз ету және т.б. қажет. Бірақ бірінші кезекте тұрақты даму үшін білім беруді тұрақты даму туралы білім ретінде түсіну мәселесін шешу қажет.

Тірек сөздер: тұрақты даму, экологиялық білім, экология, білім, декларация, ақпарат, экологияландыру.

\section{T.С. КОРОТКОВА, ${ }^{1}$}

магистр.

e-mail:ktctania@mail.ru

Д.И. ЗАКИРОВА,,$*$

$\mathrm{PhD}$.

*e-mail: ulasdila@gmail.com

${ }^{1}$ Евразийский Инновационный университет,

Казахстан, г. Павлодар

${ }^{2}$ Университет «Туран», Казахстан, г. Алматы

\section{ЭКОЛОГИЧЕСКОЕ ОБРАЗОВАНИЕ И ОБРАЗОВАНИЕ ДЛЯ УСТОЙЧИВОГО РАЗВИТИЯ: ОБЩЕЕ И ОСОБЕННОЕ}

\begin{abstract}
Аннотация
Мировоззренческую основу образования для устойчивого развития в значительной мере формирует экологическое образование. Оно является важнейшей составной частью и первой ступенью в развитии образования для устойчивого развития. В статье рассматривается взаимосвязь экологического образования и образования для устойчивого развития, их общие черты и отличительные признаки. Образование для устойчивого развития имеет неразрывную связь с экологическим образованием. Каждое из этих направлений, являясь самостоятельным, способно развиваться вместе более эффективно. Принципы, объявленные Тбилисской декларацией и столкнувшиеся с недостатками экологического образования, могут быть реализованы посредством образования для устойчивого развития. Образование в интересах устойчивого развития может эффективно использовать позитивные достижения традиционного экологического образования, дополняя его экономическими, социальными и культурными аспектами. Новая парадигма образования для устойчивого развития предполагает решение ряда задач, связанных со становлением образования в качестве главного социального института, а также с выработкой новой системы ценностей. Необходимо обеспечить тесное взаимодействие образования с социальными, политическими и культурными процессами, усилить связь образования с наукой, обеспечить информатизацию и экологизацию образования и пр. Но в первую очередь необходимо решить проблему понимания образования для устойчивого развития как образования об устойчивом развитии.
\end{abstract}

Ключевые слова: устойчивое развитие, экологическое образование, экология, образование, декларация, информация, экологизация. 